МЕЛЬКОВ Сергей Анатольевич - доктор политических наук, профессор, заведующий кафедрой государственного и муниципального управления Академии гражданской защиты МЧС России (141435, Россия, Московская обл., г. Химки, мкрн. Новогорск, стр. 1; 304304@таil.ru)

ЛЯБАХ Андрей Юрьевич - преподаватель кафедры государственного и муниципального управления Академии гражданской защиты МЧС России (141435, Россия, Московская обл., г. Химки, мкрн. Новогорск, стр. 1; 0190555@mail.ru)

ПЕРЕНДЖИЕВ Александр Николаевич - кандидат политических наук, старший преподаватель кафедры государственного и муниципального управления Академии гражданской защиты МЧС России (141435, Россия, Московская обл., г. Химки, мкрн. Новогорск, стр. 1; 000212@таіl.ru)

\section{ИССЛЕДОВАНИЕ ПОЛИТИЧЕСКОГО ПРОЦЕССА: СОЧЕТАЮТСЯ ЛИ ПРОФЕССИОНАЛИЗМ И РЕГУЛИРОВАНИЕ?}

Аннотация. В статье авторы проводят конструктивно-критический анализ научной монографии А.П. Чумаченко "Организационные аспекты регулирования политических процессов". Они рассматривают отраженные в монографии научные результаты по организации и регулированию политических процессов в РФ и формируют свои предложения автору.

Ключевые слова: государственное регулирование, механизмы властвования, политическая деятельность, политический процесс, управление, формализация

B 2017 г. в Академии гражданской защиты МЧС России была выпущена научная монография «Организационные аспекты регулирования политических процессов» [Чумаченко 2017]. Основной заслугой данного научного труда А.П. Чумаченко является аналитическая проработка следующих ключевых моментов (отметим их далее в тезисной форме).

1. Автор поставил проблему зависимости качества управленческой деятельности (в т.ч. деятельности выборного политика) от существующего в стране должностного механизма. При всей кажущейся на первый взгляд их несвязанности, зависимость качества деятельности политиков от подготовленных и профессиональных специалистов-управленцев, как мы полагаем, очевидна. Например, если это будет в нашей стране, то случайные люди не смогут победить на любых выборах власти.

2. Автор монографии постарался уйти от бытового понимания политического процесса как достаточно хаотичной и слабо организованной среды, в которой якобы всегда побеждают пролоббированные крупным капиталом или силовиками люди (есть такая точка зрения). Автор монографии старается опровергнуть взгляд на политическую деятельность как выполнение заказа, как правило, ангажированного, на такую деятельность. И А.П. Чумаченко это удалось при помощи постановки важнейшего вопроса: а где тогда государство, и в чем тогда заключается его - государства - интерес?

3. На наш взгляд, сама постановка научной проблемы - зависимость качества деятельности современных политиков от должностного механизма - является достаточно новаторской для отечественной науки. Автор монографии предлагает постепенно внедрять должностной механизм для политиков через профессиональные команды, действующие в ведущих политических партиях [Чумаченко, Устюжанинова 2017]. Если это будет в нашей стране, то политические партии, полагает автор монографии, не станут выдвигать случайных людей на выборах власти - им это будет невыгодно. 
4. В качестве позитивного момента данной научной монографии отметим стремление ее автора усилить интеграцию политической науки с реальной управленческой практикой, сблизить политологическое и управленческое знание. Такие попытки уже неоднократно предпринимались в нашей стране, в частности в многочисленных научных трудах Центра проблемного анализа и государственно-управленческого проектирования [Сулакшин, Хвыля-Олинтер 2015].

5. Не явно, но через текст монографии А.П. Чумаченко проступает его исследовательский замысел: аксиологическое обоснование должностного механизма для потенциального российского политика - ответственного и профессионального. Мы считаем, что А.П. Чумаченко не зря подчеркивает, что служение своему обществу должно стать одной из основных ценностей государственного и муниципального служащего.

И все же есть несколько конструктивно-критических моментов, на которые хотелось бы обратить внимание автора монографии и ее читателей.

Во-первых, автор рецензируемой монографии считает основным механизмом регулирования формализацию - и у нас это вызывает некоторое недопонимание. С правовой точки зрения А.П. Чумаченко, безусловно, прав, но с институциональной, как мы полагаем, формализация «может противоречить децентрализации власти, свободе создания политических партий, политической конкуренции» [Линецкий 2008]. Или другой пример - как формализация сочетается с «мягкой силой»? [Най 2014]. И т.п.

Во-вторых, когда автор монографии настаивает на универсальности механизма регулирования для всего общества, не выделяя его особенности для политического процесса, нам с этим трудно согласиться. Например, исследователи из Института социологии РАН, исследуя власть в малых российских городах, приходят к выводу, что, в отличие от мегаполисов, в некрупных российских городах сложилась не милитократия, а бизнесократия [Чирикова, Ледяев 2017]. Но ведь тогда очевидно, что исследователь, например, в этих поселениях обнаружит иные (в сравнении с мегаполисами), не универсальные механизмы властвования и управления.

B-третьих, нам показалось, что пока внутри себя А.П. Чумаченко не смог диалектически развести и свести политику (максимум властно-политического и минимум административного) и управление (обратная пропорция: минимум властно-политического и максимум административного). Возможно, что ему еще предстоит вести поиск и анализ механизмов такого сближения. Конкретизируем далее некоторые проблемные вопросы научного анализа именно такого сближения:

- процесс целеполагания в масштабе общества как процесс политический (с минимумом административного). И в этом вопросе, полагаем, должностная профессионализация (например, в экспертном сообществе) нужна, но крайне сложна для практической реализации;

- формирование того или иного вида политики как процесс максимально политический, а не административный. В этом вопросе, полагаем, должностная профессионализация (например, на уровне от заместителей министров и выше) сложна, но особенно необходима;

- реализация того или иного вида политики как процесс только управленческий (с минимумом политического). А здесь без профессионалов (на всех уровнях власти и управления) не обойтись. И т.д.

Мы бы все же порекомендовали автору монографии в будущем вернуться к анализу сущности политического как явления. Научные труды Х. Арендт, К. Шмитта, Х. Хофмайстера, Ж. де Местра, Г. Таллока, С. Ная, Ф. Хайека, А. Грамши, К. Лефор, Р. Арона, Г. Маркузе, П. Рикера, 
М. Хоркхаймера, Ч. Тейлора и еще целой плеяды ученых заслуживают продолжения их изучения автором рецензируемой монографии.

С нашей точки зрения, текст рецензируемой монографии А.П. Чумаченко будет полезен при изучении таких учебных дисциплин, как «Прогнозирование и планирование» (уровень бакалавриата), «Исследование социально-экономических и политических процессов» (уровень бакалавриата), «Управление проектами» (уровень бакалавриата), «Политический процесс, управление и регулирование» (уровень магистратуры).

Желаем тексту рецензируемой монографии долгой научной жизни. Надеемся, что монография А.П. Чумаченко будет активно использоваться в научных исследованиях экономического, социологического и политического профилей, а также в образовательном процессе в отечественных вузах.

\section{Список литературы}

Линецкий А.В. 2008. Российские институты политического представительства в условиях радикальных общественных трансформаций. Опыт сравнительного анализа. СПб: Изд-во СПбГУ. 375 с.

Най С.Дж. (младший). 2014. Будущее власти (пер. с англ. В.Н. Верченко). М.: АСТ. 444 c.

Сулакшин С.С., Хвыля-Олинтер Н.А. 2015. Мотивационная реконструкция профессиональности первого лица государства. - Труды Центра научной политической мысли и идеологии. Вып. № 14, сентябрь. М.: Наука и политика. 40 с.

Чирикова А.Е., Ледяев В.Г. 2017. Власть в малом российском городе. М.: ИД ВШЭ. 414 с.

Чумаченко А.П. 2017. Организационные аспекты регулирования политических процессов: научная монография. Химки: АГЗ МЧС России. 162 с.

Чумаченко А.П., Устюжанинова Е.В. 2017. Формирование команд по управлению проектами социально-экономического развития России. - Социальногуманитарные знания. № 3. С. 285-290.

MEL'KOV Sergey Anatol'evich, Dr.Sci. (Pol.Sci.), Professor, Head of the Chair of State and Municipal Administration, Civil Defense Academy EMERCOM of Russia (bld. 1 Novogorsk microdistrict, Khimki, Moscow Region, Russia, 141435; 304304@mail.ru)

LYABAKH Andrey Jur'evich, Lecturer of the Chair of State and Municipal Administration, Civil Defense Academy EMERCOM of Russia (bld. 1 Novogorsk microdistrict, Khimki, Moscow Region, Russia, 141435; 0190555@mail.ru)

PERENDZHIEV Aleksandr Nikolaevich, Cand.Sci. (Pol.Sci.), Senior Lecturer at the Chair of State and Municipal Administration, Civil Defense Academy EMERCOM of Russia (bld. 1 Novogorsk microdistrict, Khimki, Moscow Region, Russia, 141435;000212@mail.ru)

\section{INVESTIGATION OF THE POLITICAL PROCESS: ARE PROFESSIONALISM AND REGULATION COMBINED?}

Abstract. The paper suggests a constructive-critical analysis of the scientific monograph by A.P. Chumachenko "Organizational Aspects of Regulation of Political Processes". The authors consider the scientific results reflected in the monograph on the organization and regulation of political processes in the Russian Federation and form their proposals to the author. Keywords: state regulation, mechanisms of domination, political activity, political process, management, formalization 